\title{
CHOOSING HEATING UNITS USING THE UTILITY FUNCTION
}

\author{
G. S. Naghiu ${ }^{a}$, I. Giurca*a \\ ${ }^{a}$ Technical University of Cluj-Napoca, Faculty of Building Services Engineering, Cluj-Napoca, Romania, \\ e-mails: naghiu.george@gmail.com, * giurca_ioan@yahoo.com
}

Received: 23.02.2015 / Accepted: 13.03.2015 / Revised: 08.04.2015 / Available online: 31.05.2015

DOI: $10.1515 /$ jaes-2015-0006

KEY WORDS: Boiler, Multi-Criteria Methods, Utility Function, Central heating, Optimization, Performance

\begin{abstract}
:
In this paper, we will discuss how to choose heating units using the utility function. This paper is conceived as a detailed continuation of the analysis made by the authors in their doctoral thesis. This paper is among the first tries of this type from Romania. A case study shows the practical application of this algorithm, and the results obtained were compared to the results obtained by other authors. The paper ends with the presentation of the numerical results and a few conclusions. We are also presenting several directions for future research in this field.
\end{abstract}

\section{INTRODUCTION}

As there is a diverse range of fittings for construction, it is more and more difficult to fundament a decision on how to choose fittings for construction. Thus, in practice, in order to solve such problems, one uses the multi-criteria analysis.

Multi-criteria analysis represents a useful instrument for the decision maker when there are many decisional variants.

In the scholarly literature there are several methods for establishing the weight of the decision making criteria, there are several calculation formulas used in order to normalize the performances of the decision making variants in relation with each decision making criterion, and there are also several methods for substantiating the decisions and obviously, applying different methods may lead to slightly different results.

In this article, we used the utility function in order to analyze the method of choosing heating units.

\section{MATERIALS AND METHODS}

\subsection{Knowledge status}

At present, the decision maker may use many multi-criteria methods, each one of them pretending to be the ideal one for correctly solving a multi-criteria decision problem (Ciocalteu, 2006).

In Romania, multi-criteria methods are well known (Roman, 2012), however there are few studies about their use in the field of installations for constructions (Aşchilean, 2010, 2014), (Giurca, 2009b), (Munteanu, 2003). Starting with 1996, studies about how to choose boilers and heating units using multicriteria methods started to appear in Romania too (Badea and Bacoţiu, 1998), (Berbecaru, 1996), (Căldare, I. and Căldare, Ş., 2011), (Giurca, 2009a, 2009b), (Ilina and Lungu, 2000), (GT 038-02, 2002).

The main individual criterion and multi-criteria methods used for substantiating the decision in the field of fittings for construction are the following (Giurca, 2009b):

\footnotetext{
- the method of ordinal individual criterion ranks;

- the method of ordinal multi-criteria ranks;

- the method of real ranks;

- the method of the complex quality index;

- the method of the complex quality and economic efficiency index;

- the global performance assessment method;

- the utility method;

- the AHP method;

- the Electre method;

- the Onicescu method;
}

\footnotetext{
${ }^{*}$ Corresponding author.
} 
- the Promethee method;

- the maximum score method.

In this article, we used the utility function in order to analyze the method of choosing heating units.

The global utility function was elaborated by two researchers, namely J. von Neumann and O. Morgenstern, in 1947 (Ogarca, 2007).

The usability concept measures the importance given by the decision maker to a certain decision making variant out of a multitude of variants (Ogarca, 2007).

The decisional utility represents the decision maker's degree of satisfaction after the accomplishment of a certain consequence of the chosen variant.

For example utility method can be used in various fields, namely in the military (Petca, 2004), (Ştefănescu, 2005), in the bakery (Ogarca, 2007), in the engineering industry (Anghelache, 2006) and automotive (Şuteu, nd).

This paper is conceived as a detailed continuation of the analysis performed by the authors in their doctoral thesis.

\subsection{Stages}

Stages to be completed in the case of global utility function are the following (Image 1):

- determining the decisional versions, it supposes the elaboration of the list containing the technical solutions appropriate for the case study;

- determining the decisional criteria, it supposes the identification of the decision making criteria for which one has the information on the performances obtained by the decision making variants;

- determining the importance coefficients corresponding to decisional criteria, using, for this purpose, the matrix method;

- filling in the consequence matrix (of performances), it supposes to fill in a table comprising the values of the performances obtained by each variant, according to each corresponding criterion;

- filling in the utility matrix, it supposes to fill in a table with the values of the usability corresponding to all variants, for each and every criterion;

- choosing the optimal version, it supposes to choose the specific variant for which the greatest usability is obtained.

\section{Determining the decisional versions}

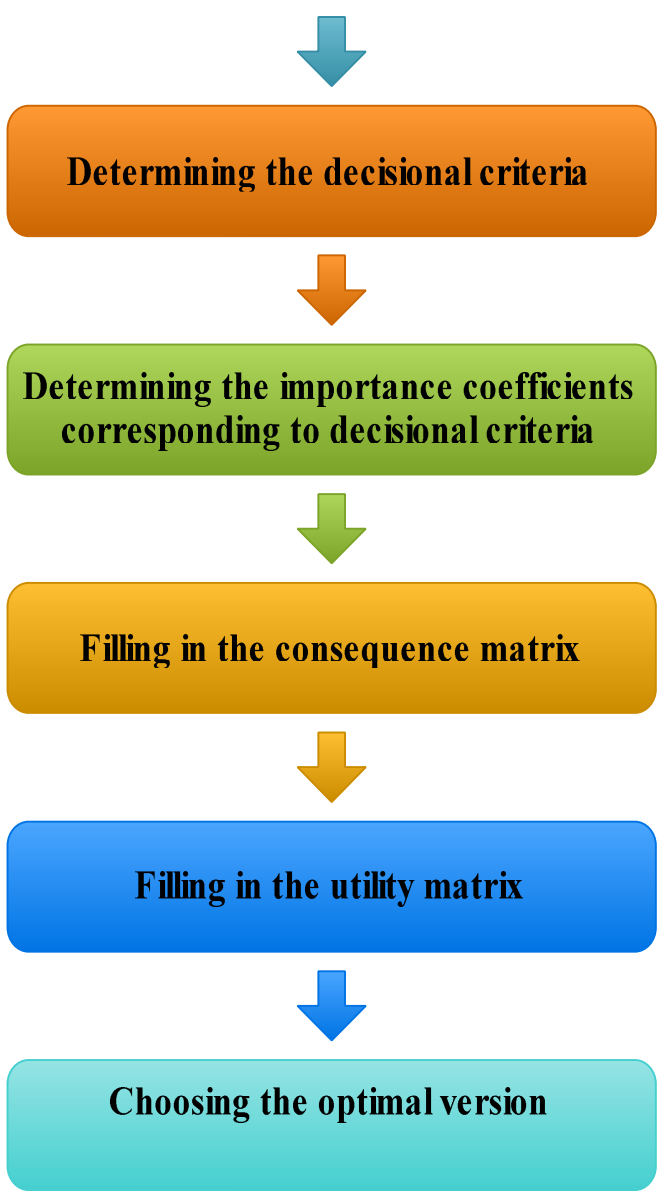

Image 1. Stages of global utility function

\subsection{Calculation algorithm}

When there are several decisional criteria, therefore certain consequences that may be expressed by different measuring units, one may use the utility in order to measure the degree in which one version is preferred to another one. Therefore, the problem is how to transform all consequences into utilities that must correctly prioritize the decisional versions (Petca, nd.).

\section{a) Utility calculation}

Depending on the nature of the criteria, the utilities will be calculated according to the following formulas (Petca, nd.):

Maximizing criteria:

$$
u_{i j}=\begin{gathered}
a_{i j}-a_{\min i} \\
a_{\max j}-a_{\min j}
\end{gathered}
$$


Minimizing criteria:

$$
u_{i j}=\frac{a_{\max i}-a_{i j}}{------------}
$$

where:

uij represents the usability of the $i$ variant according to the $j$ criterion;

amax $\mathrm{j}$ - the maximum performance obtained by the analyzed variants, according to the $\mathrm{j}$ criterion;

amin $\mathrm{j}$ - the minimum performance obtained by the analyzed variants, according to the $\mathrm{j}$ criterion;

aij - the performance obtained by the $\mathrm{i}$ variant according to the $\mathrm{j}$ criterion.

One utility corresponds to each consequence (Petca, nd.).

The usability shall take values comprised in the $[0,1]$ range.

\section{b) Choosing optimal version}

Importance coefficients of the criteria may be identical or differentiated.

b.1 According to this method, if the importance coefficients of the criteria are identical (which have equal values), the optimal version corresponds to the one for which the utility sum is maximum, i.e. (Costea, 1996) - (Petca, nd.):

$$
\text { Vopt }=\max \sum_{\mathrm{i}=1}^{\mathrm{m}} \mathrm{Uij}
$$

where:

Uij represents the utility of , ," version according to the , $\mathrm{j}$ " criterion (Petca, nd.).

b. 2 If the value of the importance coefficients is different for the decisional criteria, the optimal version is the one for which the sum of the products between the utilities and the importance coefficients is maximum, i.e. (Costea, 1996), (Petca, nd.):

$$
\text { Vopt }=\max \sum_{\mathrm{i}=1}^{\mathrm{m}} \mathrm{Uij} \cdot \mathrm{Kj}
$$

where:

$\mathrm{Kj}$ represents the importance share of the decisional criteria.

The importance weight of the decision making criteria shall be established using the matrix method.

One shall elaborate a matrix containing the decision making criteria on the row as well as on the column, and the matrix elements shall be established as follows:

- value 0 if the $\mathrm{i}$ criterion is less important than the $\mathrm{j}$ criterion,

- value 0.5 if the $i$ criterion is just as important as the $j$ criterion,

- value 1 if the $i$ criterion is more important than the $\mathrm{j}$ criterion;

- value 1 on the matrix diagonal.
Then, one shall calculate, for each row, the sum of values corresponding to each and every criterion. Moving on, one shall determine the weights corresponding to the decision making criteria in relation to the total value. Obviously, the sum of the importance coefficients must equal the digit one, and the importance coefficients shall take values comprised within the $[0,1]$ range.

\section{RESULTS AND DISCUSSIONS}

\subsection{Case study}

We present bellow a case study related to how to choose heating units using the utility function.

The data presented in table 1 , table 2 and table 3 were taken over directly from the paper (Ilina and Lungu, 2000).

\subsubsection{Set of decisional versions}

We take into account 4 mini-heating units marked P1, P2, P3 and P4 (Ilina and Lungu, 2000).

In table no. 1 we presented the set of versions [Vi].

\begin{tabular}{|c|c|}
\hline $\mathrm{V}_{\mathrm{i}}$ & Name \\
\hline $\mathrm{V}_{1}$ & $\mathrm{P}_{1}$ \\
\hline $\mathrm{V}_{2}$ & $\mathrm{P}_{2}$ \\
\hline $\mathrm{V}_{3}$ & $\mathrm{P}_{3}$ \\
\hline $\mathrm{V}_{4}$ & $\mathrm{P}_{4}$ \\
\hline
\end{tabular}

Table 1. Set of versions [Vi] (after Ilina and Lungu, 2000)

\subsubsection{Set of decisional criteria}

Out of the set of characteristics of one mini-heating unit, we have chosen as analysis characteristics: lifespan, nominal thermal power, nominal output, automation degree, accessories, template, electrical power, noise level and price.

In order to make this study, the following classification of the above mentioned features is also useful, namely:

- features directly proportional to the product's quality (the bigger is the value of the quantity associated to the feature, the more product quality increases): lifespan, nominal thermal power, nominal output, automation degree, accessories;

- features inversely proportional to the product quality (the smaller is the value of the quantity associated to the feature, the more product quality increases): template, electrical power, noise level, price (Ilina and Lungu, 2000).

We set the following objectives:

- maximization of the lifespan of heat-only boiler stations in order to cut the costs during the product's lifespan, $\mathrm{C} 1$ criterion; - maximization of the nominal thermal power of the heat-only boiler stations, $\mathrm{C} 2$ criterion; 
- maximization of the nominal output of the heat-only boiler stations in order to decrease fuel consumption as well as to decrease pollution level, C3 criterion;

- maximization of the automation degree of the boilers in order to decrease fuel consumption as well as to decrease pollution level, C4 criterion;

- maximization of the accessories placed on the heat-only boiler stations in order to cut on the investment costs, C5 criterion;

- decrease of the gauge of the heat-only boiler stations in order to decrease the construction surface occupied by the heat-only boiler stations, $\mathrm{C} 6$ criterion;

- decrease of the installed power capacity of the heat-only boiler stations in order to cut on the power operation costs, C7 criterion;

- decrease of the noise level of the heat-only boiler stations in order to increase the comfort level for the consumers who use those heat-only boiler stations, $\mathrm{C} 8$ criterion.

In table no. 2, we presented the set of decisional criteria [Cj].

\begin{tabular}{|c|l|c|c|}
\hline $\mathrm{C}_{\mathrm{j}}$ & \multicolumn{1}{|c|}{ Criterion Name } & M.U. & Nature \\
\hline $\mathrm{C}_{1}$ & Lifespan & years & maximizing \\
\hline $\mathrm{C}_{2}$ & $\begin{array}{l}\text { Nominal thermal } \\
\text { power }\end{array}$ & $\mathrm{kW}$ & maximizing \\
\hline $\mathrm{C}_{3}$ & Nominal output & $\%$ & maximizing \\
\hline $\mathrm{C}_{4}$ & Automation degree & & maximizing \\
\hline $\mathrm{C}_{5}$ & Accessories & & maximizing \\
\hline
\end{tabular}

\subsection{The obtained results}

We established the importance coefficients using the matrix method, and we presented the results in table no. 4 .

\begin{tabular}{|c|l|c|c|}
\hline $\mathrm{C}_{6}$ & Template & & minimizing \\
\hline $\mathrm{C}_{7}$ & Electrical power & $\mathrm{W}$ & minimizing \\
\hline $\mathrm{C}_{8}$ & Noise level & $\mathrm{dB}(\mathrm{A})$ & minimizing \\
\hline
\end{tabular}

Table 2. Set of Criteria [Cj] (after Ilina and Lungu, 2000)

\subsubsection{Set of assessment criteria consequences}

The consequence matrix (table no. 3) contains the values of the quantities characterizing these products (price, nominal thermal power, template, etc.). The values necessary for the study are offered directly by the manufacturer in the documentation. For other features (automation degree and accessories), an assessment is made based on the information found in the documentation, using grades from 1 to 3 (where 1 is the lowest grade and 3 is the highest grade) (Ilina and Lungu, 2000).

For the example studied, the data obtained shall be centralized in table no. 3 .

\begin{tabular}{|c|c|c|c|c|c|c|c|c|}
\hline \multirow{2}{*}{$\mathrm{V}_{\mathrm{i}}$} & \multicolumn{7}{|c|}{$\mathrm{C}_{\mathrm{j}}$} \\
\cline { 2 - 10 } & $\mathrm{C}_{1}$ & $\mathrm{C}_{2}$ & $\mathrm{C}_{3}$ & $\mathrm{C}_{4}$ & $\mathrm{C}_{5}$ & $\mathrm{C}_{6}$ & $\mathrm{C}_{7}$ & $\mathrm{C}_{8}$ \\
\hline $\mathrm{V}_{1}$ & 22 & 42 & 92.5 & 3 & 2 & 0.823 & 130 & 65 \\
\hline $\mathrm{V}_{2}$ & 15 & 40.7 & 90 & 2 & 1 & 0.513 & 150 & 55 \\
\hline $\mathrm{V}_{3}$ & 20 & 47.2 & 92 & 1 & 2 & 0.533 & 100 & 60 \\
\hline $\mathrm{V}_{4}$ & 20 & 47 & 92 & 3 & 3 & 1.273 & 130 & 65 \\
\hline
\end{tabular}

Table 3. Consequence matrix [aij] (after Ilina and Lungu, 2000)

After making the necessary calculations, the results were synthesized in the utility matrix. For details, please see the table no. 5 .

\begin{tabular}{|c|c|c|c|c|c|c|c|c|c|c|c|}
\hline \multirow[t]{2}{*}{ No. } & \multirow[b]{2}{*}{$\mathrm{C}_{\mathrm{j}}$} & \multicolumn{8}{|c|}{$\mathrm{C}_{\mathrm{j}}$} & \multirow[t]{2}{*}{ Total } & \multirow{2}{*}{$\begin{array}{c}\text { Importance share of the } \\
\text { decisional criteria }\end{array}$} \\
\hline & & $\mathrm{C}_{1}$ & $\mathrm{C}_{2}$ & $\mathrm{C}_{3}$ & $\mathrm{C}_{4}$ & $\mathrm{C}_{5}$ & $\mathrm{C}_{6}$ & $\mathrm{C}_{7}$ & $\mathrm{C}_{8}$ & & \\
\hline 1 & $\mathrm{C}_{1}$ & 1 & 1 & 1 & 1 & 1 & 1 & 1 & 1 & 8 & 0.2105 \\
\hline 2 & $\mathrm{C}_{2}$ & 0 & 1 & 1 & 1 & 1 & 1 & 1 & 1 & 7 & 0.1842 \\
\hline 3 & $\mathrm{C}_{3}$ & 0 & 0 & 1 & 1 & 1 & 1 & 1 & 1 & 6 & 0.1579 \\
\hline 4 & $\mathrm{C}_{4}$ & 0 & 0 & 0 & 1 & 1 & 1 & 0.5 & 0 & 3.5 & 0.0921 \\
\hline 5 & $\mathrm{C}_{5}$ & 0 & 0 & 0 & 1 & 1 & 1 & 0 & 0 & 3 & 0.0789 \\
\hline 6 & $\mathrm{C}_{6}$ & 0 & 0 & 0 & 1 & 0 & 1 & 0 & 0 & 2 & 0.0526 \\
\hline 7 & $\mathrm{C}_{7}$ & 0 & 0 & 0 & 0.5 & 1 & 1 & 1 & 0.5 & 4 & 0.1053 \\
\hline 8 & $\mathrm{C}_{8}$ & 0 & 0 & 0 & 1 & 1 & 1 & 0.5 & 1 & 4.5 & 0.1184 \\
\hline 9 & Total & & & & & & & & & 38 & 1.0000 \\
\hline
\end{tabular}

Table 4. Calculation of the importance weight using the matrix method 


\begin{tabular}{|c|c|c|c|c|c|c|c|c|c|}
\hline \multirow[t]{5}{*}{ Version } & \multicolumn{8}{|c|}{ Importance coefficients } & \multirow{5}{*}{$\begin{array}{c}\text { Utility } \\
\text { sum }\end{array}$} \\
\hline & K1 & $\mathrm{K} 2$ & K3 & K4 & K5 & K6 & K7 & K8 & \\
\hline & 0.2105 & 0.1842 & 0.1579 & 0.0921 & 0.0789 & 0.0526 & 0.1053 & 0.1184 & \\
\hline & \multicolumn{8}{|c|}{ Criteria } & \\
\hline & $\mathrm{C} 1$ & $\mathrm{C} 2$ & $\mathrm{C} 3$ & $\mathrm{C} 4$ & C5 & C6 & $\mathrm{C} 7$ & $\mathrm{C} 8$ & \\
\hline $\mathrm{V}_{1}$ & 1.00 & 0.20 & 1.00 & 0.00 & 0.50 & 0.41 & 0.40 & 0.00 & 3.51 \\
\hline $\mathrm{V}_{2}$ & 0.00 & 0.00 & 0.00 & 0.50 & 1.00 & 0.00 & 0.00 & 1.00 & 2.50 \\
\hline $\mathrm{V}_{3}$ & 0.71 & 1.00 & 0.80 & 1.00 & 0.50 & 0.03 & 1.00 & 0.50 & 5.54 \\
\hline $\mathrm{V}_{4}$ & 0.71 & 0.97 & 0.80 & 0.00 & 0.00 & 1.00 & 0.40 & 0.00 & 3.88 \\
\hline
\end{tabular}

Table 5. Utility matrix [uij]

In the following table, we synthetically presented the classification of versions depending on the sum of utilities.

\begin{tabular}{|c|c|c|c|}
\hline $\mathrm{Vi}$ & Name & $\square \mathrm{Ui}$ & Place \\
\hline $\mathrm{V}_{1}$ & $\mathrm{P} 1$ & 3.51 & 3 \\
\hline $\mathrm{V}_{2}$ & $\mathrm{P} 2$ & 2.50 & 4 \\
\hline $\mathrm{V}_{3}$ & $\mathrm{P} 3$ & 5.54 & 1 \\
\hline $\mathrm{V}_{4}$ & $\mathrm{P} 4$ & 3.88 & 2 \\
\hline
\end{tabular}

Table 6. Ranking technical solutions depending on the sum of utilities

In the following table, we synthetically presented the classification of versions depending on the global utility.

\begin{tabular}{|c|c|c|c|}
\hline $\mathrm{Vi}$ & Name & $\square \mathrm{Ui} \cdot \mathrm{Kj}$ & Place \\
\hline $\mathrm{V}_{1}$ & $\mathrm{P} 1$ & 0.51 & 3 \\
\hline $\mathrm{V}_{2}$ & $\mathrm{P} 2$ & 0.24 & 4 \\
\hline $\mathrm{V}_{3}$ & $\mathrm{P} 3$ & 0.76 & 1 \\
\hline $\mathrm{V}_{4}$ & $\mathrm{P} 4$ & 0.55 & 2 \\
\hline
\end{tabular}

Table 7. Ranking technical solutions depending on the global utility

\subsection{Discussions}

After analyzing the data presented in table no. 6 and table no. 7, we noticed that in the case of the analysis of versions depending on the sum of utilities, as well as in the case of the analysis of versions depending on the global utility, the ranking of the technical solutions is the same.

Analyzing the ranking obtained in this paper by using the utility function, and the ranking determined by the authors in the papers (Giurca, 2009a, 2009b), where he used three multicriteria methods, namely the comparative analysis method, the complex quality indicator method and the complex quality and economic efficiency indicator method.

Also in the works (Giurca, 2009a, 2009b) for complex quality indicator method and complex method indicator of quality and economic efficiency, significant coefficients were determined using the method of experts and the matrix method and synthesis of the results is presented in table below.

\begin{tabular}{|c|c|c|c|}
\hline No. & $\mathrm{V}_{\mathrm{i}}$ & $\begin{array}{c}\text { The variant's } \\
\text { best place }\end{array}$ & $\begin{array}{c}\text { The variant's } \\
\text { worst place }\end{array}$ \\
\hline 1 & $\mathrm{~V}_{1}$ & 2 & 2 \\
\hline 2 & $\mathrm{~V}_{2}$ & 1 & 4 \\
\hline 3 & $\mathrm{~V}_{3}$ & 1 & 4 \\
\hline 4 & $\mathrm{~V}_{4}$ & 1 & 4 \\
\hline
\end{tabular}

Table 8. Synthesis of the variant classification (Giurca, 2009a; Giurca, 2009b)

Resulted that using different multi-criteria methods may lead to obtaining different results, even when the various technical solutions were analyzed based on the same consequences.

The results obtained were also compared to the results obtained by other authors (Ilina and Lungu, 2000), and the conclusion is that the multi-criteria method may influence the final ranking of the technical solutions.

\section{CONCLUSIONS}

When choosing technical solutions based on multi-criteria methods, the final ranking may be influenced by the multicriteria method used.

From the simulations made by the authors, it results that the multi-criteria methods may offer important information related to the selection of the best technical solution.

The method presented may be used for:

- designing central heating systems;

- assessing the performance of various types of materials from the field of installations for constructions;

- assessing the performance of materials form other fields of activity.

The results from the analysis that the method can be used utilities in the background and optimize decision from various fields. 


\section{REFERENCES}

Așchilean, I., Contribuţii teoretice şi experimentale la reabilitarea şi modernizarea sistemelor de alimentare cu apă a localităţilor urbane (Theoretical and experimental contributions regarding the rehabilitation and modernization of urban water supply). Teză de doctorat. Universitatea Tehnică din ClujNapoca, Facultatea de Instalaţii, 2010, pagina 252-256.

Așchilean, I., Reabilitarea şi modernizarea sistemelor de alimentare cu apă a localităţilor urbane (Rehabilitation and modernization of water supply in urban), Editura Risoprint, Cluj-Napoca, 2014.

Badea, G., Bacoţiu, C., Alegerea echipamentelor de instalaţii - o problemă multicriterială (Choosing equipment installations - a multicriteria problem). A XXXIII-a Conferinţă Naţională de Instalaţii, Sinaia, 20-23 octombrie 1998, România, pp.15-20.

Berbecaru, D., Elemente de evaluare pentru un top al echipamentelor de instalaţii (Elements of evaluation for top installation equipment). A $X X X-A$ Conferinţă de instalaţii, Sinaia, 16-18 octombrie 1996, România, pp.35-37.

Căldare, I., Căldare, Ş., Metoda de evaluare globală a performanţelor energetice ale instalaţiilor de încălzire centrală şi de preparare a apei calde de consum. Cerinţe esenţiale de calitate şi criterii de performanţă pentru clădirile publice (Comprehensive evaluation method the energy performance of central heating installations and hot water consumption. Essential requirements for quality and performance criteria for public buildings). Internaţional Conference „Building services and ambiental comfort $-20^{\text {th }}$ edition, Aprilie 7-8, 2011, Timişoara, România, pp.580-593.

Ciocalteu, C., Managementul modernizării armatei în procesul de aderare a României la structurile de securitate europene şi euroatlantice (Army Modernization Management in the Process of Romania's Joining the European and Euro Atlantic Security Structures). Teză de doctorat, Academia de Studii Economice, Bucureşti, 2006, pp. 127.

Costea, V., Managementul firmei de instalații-montaj (Company management installation and assembly), Editura Mesagerul, Cluj-Napoca, 1996, pp.107.

Giurca, I., Alegerea centralelor termice cu ajutorul metodelor multicriteriale (Choosing thermal plants using multicriteria methods). Revista Tehnologiile Energiei producerea, transportul şi distribuţia energiei electrice şi termice, nr. $11 / 2009 a$

Giurca, I., Contribuţii privind alimentarea cu energie termică a ansamblurilor de locuinte, utilizând agenți termici cu parametri scăzuţi (Contributions to thermic energy supplies of building assemblies by using thermic agents with low parameters). Teză de doctorat, Universitatea Tehnică din Cluj-Napoca, Facultatea de Instalaţii, Cluj-Napoca, 2009b, pp.231-336.

Ilina, M., Lungu, C., Analiza structurii sortimentale şi a calităţii microcentralelor termice (The analysis of assortment and quality heating boilers). Buletin Informativ - Radet, nr. 1/2000, pp.1922.
Munteanu, A., Optimizarea constructivă a rețelei electrice de distribuţie din incinta consumatorului (Optimizing design of electric distribution network inside the consumer). Teză de doctorat, Universitatea Tehnică din Cluj-Napoca, Facultatea de Construcţii, Cluj-Napoca, 2003.

Ogarca, G., Metode şi tehnici de perfecţionare a abordării deciziilor în întreprinderile din industria panificaţiei din zona Oltenia (Methods and techniques to improve decision approach in the bakery industry enterprises Oltenia). Teză de doctorat. Academia de Studii Economice, Facultatea de Management, Bucureşti, 2007, pp.241-242.

Petca, I., Curs Management. Partea V - Luarea deciziilor in organizaţia militară (Management Course. $5^{\text {th }}$ Part - Decision making process in the military organization). Academia Forţelor Terestre din Sibiu.

Roman, M., Manual - Analiza multicriterială (Handbook Multi-criteria Analysis), 2012.

Ștefănescu, T., Contribuţii privind utilizarea tehnicilor informatice în sistemul de pregătire al armatei (Contributions to the use of computer techniques in the army training system). Rezumat - Teză de doctorat, Academia Tehnică Militară, Bucureşti, 2005, pp.44- 45.

Şuteu Sorin, Modele de fundamentare a deciziilor. Suport de curs (Decision substantiating methods. Syllabus), Universitatea Tehnică din Cluj-Napoca. Disponibil la http://www.mim.utcluj.ro/, accesat în data de 06.04.2015.

*** GT 038-02, Ghid pentru determinarea performanţelor energetice ale instalaţiilor de încălzire şi de apă caldă de consum din clădirile social-culturale existente, în vederea reabilitării şi modernizării acestora (Guidelines for determining the energy performance of heating and hot water consumption in existing social and cultural buildings, the rehabilitation and modernization of their), pp.126; 137; 138. 